\title{
RESULTS OF PROCESSING OF CCD OBSERVATIONS OF SELECTED OPEN CLUSTERS ON MAIDANAK
}

\author{
Yu.I. Protsyuk ${ }^{1}$, Sh.Sh. Shukhratov ${ }^{2}$, O.M. Kovalchuk ${ }^{1}$, M.M. Muminov ${ }^{3}$, Q.H. Yuldoshev ${ }^{2}$, \\ R.R Abdurakhimov ${ }^{3}$, V.M. Andruk ${ }^{4}$ \\ ${ }^{1}$ Research Institute "Mykolaiv Astronomical Observatory", Mykolaiv, Ukraine, \\ yuri@nao.nikolaev.ua \\ ${ }^{2}$ Ulugh Beg Astronomical Institute UAS, Tashkent, Uzbekistan, qudratillo@astrin.uz \\ ${ }^{3}$ Andijan State University, Andijan, Uzbekistan, muminov1951@gmail.com \\ ${ }^{4}$ Main Astronomical Observatory NASU, Kyiv, Ukraine, andruk@mao.kiev.ua
}

\begin{abstract}
Observations of 20 open clusters at the Maidanak Observatory were performed using the Zeiss1000 telescope in the winter of 2018. As the light receiver, a CCD camera Apogee Alta U9000 (3K x 3K, FOV $\left.19.5^{\prime} \times 19.5^{\prime}\right)$ was used. All observations were performed using BVRI light filters. The exposure time, depending on the filter was from 60 to 150 seconds. Due to the instability of the telescope, images of the stars are slightly elongated. For each observation night, calibration images were obtained. Astrometric processing was carried out after filtering hot pixels. For testing purposes, we used two methods of reduction: by the Astrometrica program and the author's set of programs with primary processing in the MIDAS environment. The reduction of 280 frames was performed using a polynomial of the third degree. As reference stars in different processing options, the Tycho2, UCAC4 and Gaia
\end{abstract} DR2 catalogs were used. Due to the small field and the small number of reference stars, the processing in Tycho2 showed the worst result. The results obtained by author programs with reference catalogs UCAC4 and Gaia, showed good convergence. Integrated catalog of 18 thousand stars upto $18.5^{\mathrm{m}}$ was obtained. The accuracy of the catalog is $\sigma_{\mathrm{RA}}=0.011 "$ and $\sigma_{\mathrm{DEC}}=0.013 "$, the accuracy of single observation on RA (0.030 - 0.032)" and DEC (0.035 - 0.037)". At the same time, the accuracy of intraframe processing with the Gaia reference catalog turned out to be 2-3 times better than the analogous one with the UCAC4 catalog. The accuracy of processing elongated star images by the Astrometrica program is on the average 3-4 times worse than by the author's programs. Also a systematic dependence of the pixel scale on the using filter was found. Based on the results of the test photometric processing of NGC 869 cluster a photometric estimate of the accuracy of the observations was obtained. The internal errors of one measurement of the stellar magnitude in the instrumental system bvr have the values $\sigma_{\text {bvr }}=(0.03-0.05)^{\mathrm{m}}$. After the reduction of instrumental stellar magnitudes to the Johnson BVR system, the errors of one measurement are $\sigma_{\mathrm{BVR}}=(0.05-0.08)^{\mathrm{m}}$. The processing of observations showed the possibility of carrying out differential observations on the telescope Zeiss-1000 with an accuracy of one observation, not worse than $0.04 "$, and near 0.02 " after improving telescope management.

Keywords: Astrometry - Photometry - Open clusters Data analysis - Catalogues

АБСТРАКТ. Спостереження 20 розсіяних зоряних скупчень на Майданакській обсерваторії виконані на метровому телескопі Zeiss -1000 взимку 2018 року. Як приймач випромінювання використовувалася ПЗ3 камера Apogee Alta U9000 (3K x 3K, FOV 19,5'x19,5'). Bci спостереження виконані 3 використанням світлових фільтрів BVRI в системі Бесселя. Тривалість експозиції в залежності від фільтра становила від 60 до 150 секунд. Через нестабільність ведення телескопа зображення зірок трохи витягнуті. Для кожної спостережної ночі отримані калібрувальні зображення. Астрометрична обробка проводилася після фільтрації гарячих пікселів за двома методиками: програмою Astrometrica i авторським набором програм 3 первинною обробкою в середовищі MIDAS. Редукція виконувалася з використанням полінома 3-го ступеня. В якості опорних зірок в різних варіантах обробки були використані каталоги Tycho2, UCAC4 i Gaia DR2. Через малий розмір поля i малу кількість опорних зірок обробка в Тусhо2 показала найгірший результат. Результати, отримані авторськими програмами 3 опорними каталогами UCAC4 i Gaia, показали хорошу збіжність. Точність інтегрального каталогу 18 тисяч зірок до $18.5^{\mathrm{m}}$, отриманого з 280 кадрів, склала по RA - 0.011" і DEC - 0.013". Точність одиничного спостереження склала по RA (0.030 $0.032) "$ і DEC (0.035 - 0.037)". При цьому точність внутрішньо кадрової обробки з опорним каталогом Gaia виявилася в 2-3 рази краще аналогічної з каталогом UCAC4. Точність обробки витягнутих зображень програмою Astrometrica в середньому в 3-4 рази гірше, ніж авторськими програмами. Також в процесі обробки виявлена систематична залежність величини масштабу пікселя від застосовуваного світлофільтру. За результатами тестової обробки спостережень від 21 січня 2018 p скупчення NGC869 отримана фотометрична оцінка 
точності спостережень. Внутрішні помилки одного виміру зоряної величини в інструментальній системі bvr мають значення $\sigma_{\mathrm{bvr}}=(0.03-0.05)^{\mathrm{m}}$. Після редукції інструментальних зоряних величин в систему BVR Джонсона помилки одного виміру рівні $\sigma_{\mathrm{BVR}}=(0.05$ $0.08)^{\mathrm{m}}$. Обробка спостережень показала можливість проводити диференціальні спостереження на телескопі Zeiss-1000 з точністю одного спостереження не гірше 0."04, а при поліпшенні ведення телескопа, то і 0.02".

Ключові слова: Астрометрія - Фотометрія - Розсіяні скупчення - Аналіз даних - Каталоги

\section{Introduction}

Observations of 20 open clusters (NGC869, NGC884, NGC957, NGC1039, NGC1245, NGC1444, NGC1496, NGC1528, NGC1545, NGC1907, NGC2099, NGC2168, NGC2281, NGC2331, NGC2335, NGC2420, NGC2632, NGC2682, Berkeley10, Berkeley67) at the Maidanak Observatory(http://www.academy.uz/en/site/slideview/20) were performed using the Zeiss-1000 telescope in the winter of 2018. As the light receiver, a CCD camera Apogee Alta U9000 was used. New CCD Camera was installed at 2017 after repairing of the telescope. Camera has $3 \mathrm{~K} \times 3 \mathrm{~K}$ size with FOV $19.5^{\prime} \times 19.5^{\prime}$ and pixel size $12 \mathrm{x}$ 12 microns or $0.388 \% /$ pixel. All observations were performed using BVRI light filters with three exposures each. The exposure time, depending on the filter was from 60 to 150 seconds with CCD chip temperature near $-20^{\circ} \mathrm{C}$. Due to the instability of the telescope, images of the stars are slightly elongated. For each observation night, calibration images were obtained. Astrometric processing was carried out after filtering hot pixels. For testing purposes, we used two methods of reduction: by the Astrometrica program (Raab, 2018) and the author's set of programs with primary processing in the MIDAS environment (Andruk et al., 2005; 2017; Protsyuk et al., 2014a, 2014b). This software was created to process images that are part of the Ukrainian Virtual Observatory (Vavilova et al., 2012; 2017).

\section{Astrometric investigations}

The reduction of 280 frames was performed using a polynomial of the third degree. As reference stars in different processing options, the Tycho2, UCAC4 (Zacharias et al., 2013) and Gaia DR2 (Gaia Collaboration, 2018) catalogs were used. Due to the small field and the small number of reference stars, the processing in Tycho 2 showed the worst result. The results obtained by author programs with reference catalogs UCAC4 and Gaia DR2, showed good convergence (Fig.1). Integrated catalog of 18 thousand stars upto $18.5^{\mathrm{m}}$ was obtained. The accuracy of the catalog is $\sigma_{\mathrm{RA}}=0.011$ " and $\sigma_{\mathrm{DEC}}=0.013 "$, the accuracy of single observation on RA (0.030 - 0.032)" and DEC (0.035 - 0.037)" (Fig. 2).
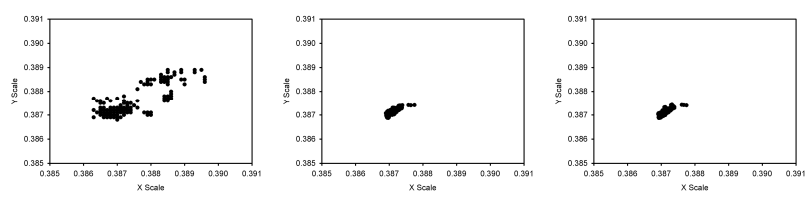

Figure 1: Scale values distribution for all CCD frames depending on the reference catalog Tycho2, UCAC4, Gaia

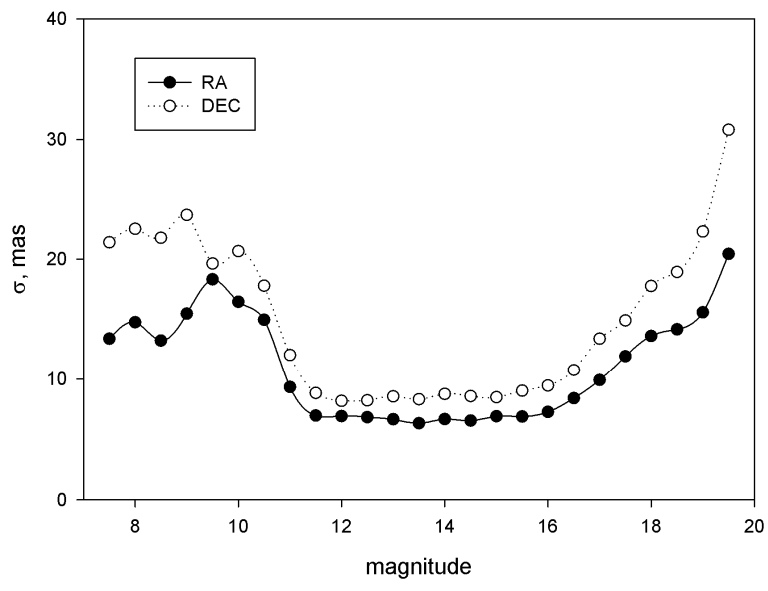

Figure 2: Distribution of catalog accuracy from magnitude, reference catalog Gaia

At the same time, the accuracy of intraframe processing with the Gaia DR2 reference catalog turned out to be 2-3 times better than the analogous one with the UCAC4 catalog (Fig. 3). The accuracy of processing elongated star images by the Astrometrica program is on the average 3-4 times worse than by the author's programs (Table 1). Also a systematic dependence of the pixel scale on the using filter was found (Fig. 4).
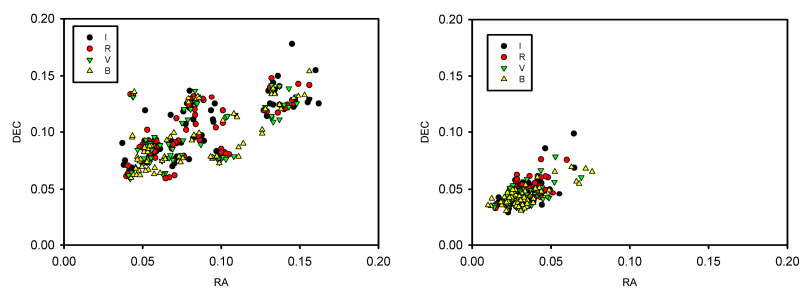

Figure 3: Distribution of RA/DEC accuracy in arcsec of intraframe processing with the reference catalogs UCAC4 (left) and Gaia DR2 (right)
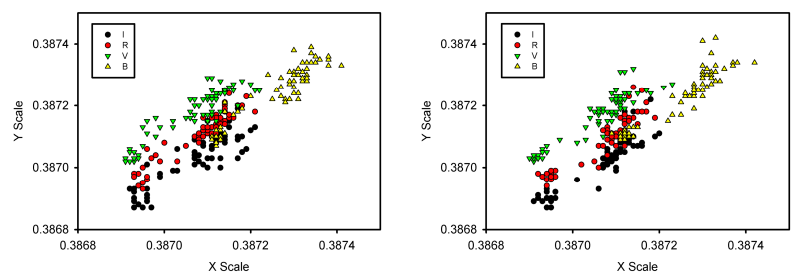

Figure 4: Systematic dependence of the pixel scale on the using filters BVRI for the reference catalogs UCAC4 (left) and Gaia DR2 (right) 
Table 1: Comparison of the accuracy of single observation with different reductions

\begin{tabular}{|c|c|c|c|c|c|}
\hline Software & Ref.cat & $\begin{array}{c}\text { N ref. } \\
\text { stars }\end{array}$ & $\begin{array}{c}\text { N } \\
\text { stars }\end{array}$ & $\begin{array}{c}\text { RA, } \\
\text { mas }\end{array}$ & $\begin{array}{c}\text { DEC, } \\
\text { mas }\end{array}$ \\
\hline Astrometrica & UCAC4 & 15516 & 28293 & 96.7 & 164.9 \\
\hline Author's & UCAC4 & 12771 & 18288 & 31.2 & 37.0 \\
\hline Author's & Gaia & 13295 & 18192 & 29.8 & 34.8 \\
\hline
\end{tabular}

Table 1 show the number of reference stars, number of stars in received catalogs and accuracy of single observation for this catalogs. Astrometrica finded more objects but overall accuracy worse. Despite the greater accuracy of intraframe processing with Gaia reference catalog (Fig. 3) we received approximate equality of the accuracy of the resulting catalogs for both reference catalogs. This is associated with the worsing of the final result due to the instability of the telescope from frame to frame and a rather large random error.

\section{Photometric investigations}

CCD observations of open clusters are made by consecutive exposures in each of the Johnson BVRI filters. The duration of one exposure are 60,90,120 and 150 seconds for I, R, V and B filters respectively. The processing of raw $\mathrm{CCD}$ frames with $\mathrm{B}, \mathrm{V}, \mathrm{R}$ filters was made according to the method of processing digitized images of star fields, which is described by Andruk et al. $(2005 ; 2017)$. The demonstration of the evaluation of the photometric accuracy of processing CCD frames is considered on the example of observations from January 21, 2018 of the NGC 869 cluster. Figure 5 shows the distribution over the stellar magnitudes of the internal errors of a single measurement of the magnitude in the bvr instrumental system. The figure shows that the internal errors of one measurement of the magnitude in the bvr instrumental system have the values $\sigma_{\mathrm{bvr}}=(0.03-0.05)^{\mathrm{m}}$.
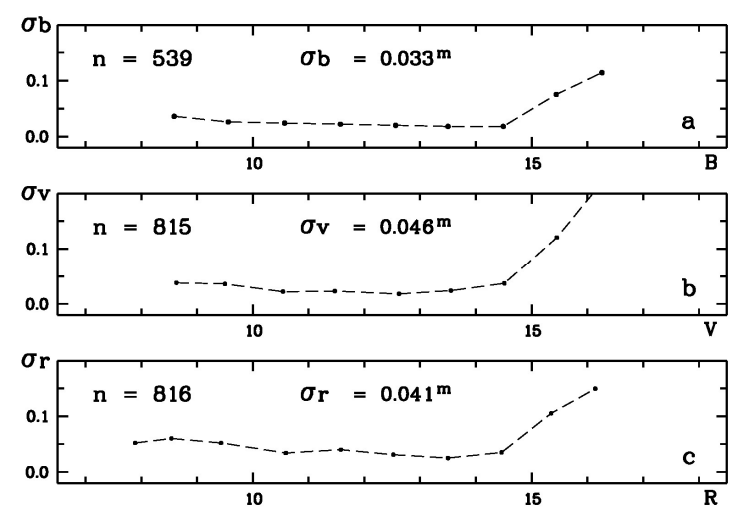

Figure 5: The distributions over the stellar magnitudes of the internal errors of a single measurement of the magnitude in the bvr instrumental system
Also in the figure for each band $b, v, r$ show the number of stars $\mathrm{n}$ on frames. The procedure for reducing the instrumental stellar b, v, $r$ to the Johnson system B, V, R is shown in Fig. 6. For searching an functional connection of Johnson's B, V, and $\mathrm{R}$ values with instrumental photometric values of $b, v$, and $r$ we used photoelectric measurements of stars from the Relke et al. (2015) catalog. After the reduction of instrumental stellar influences in the Johnson BVR system, the errors of one dimension are $\sigma_{\mathrm{BVR}}=(0.05-0.08)^{\mathrm{m}}$. These results are presented in Fig. 7.
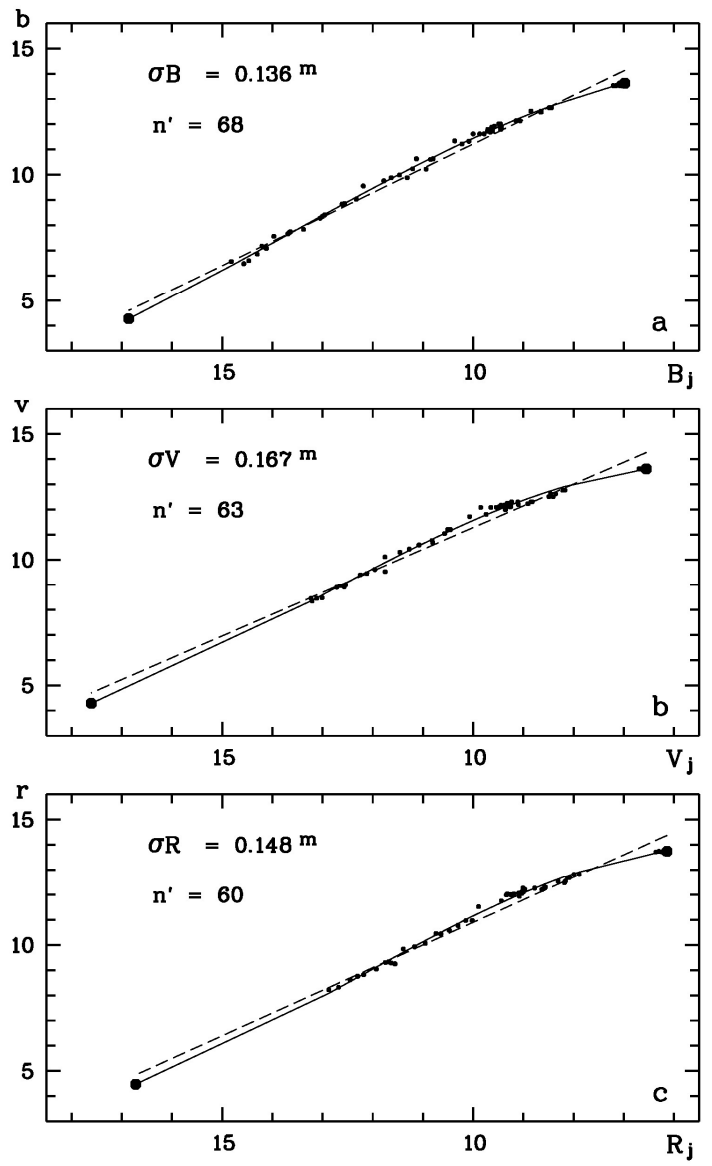

Figure 6: Connection of instrumental stellar magnitudes bvr with a system of stellar magnitudes BVR Johnson
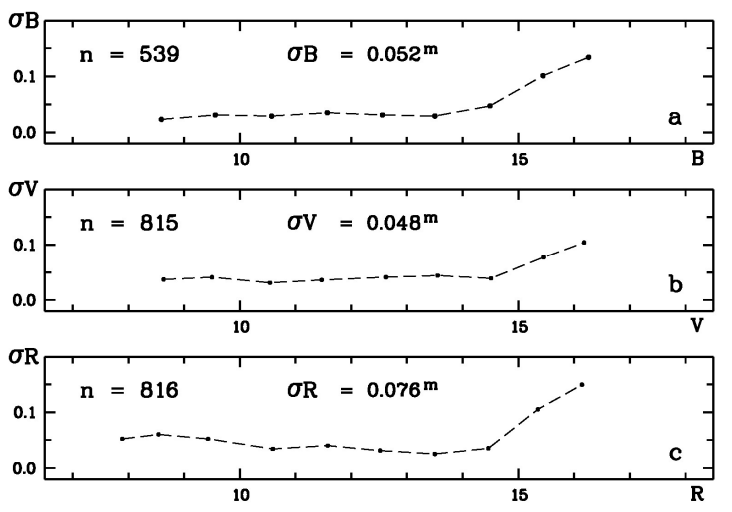

Figure 7: The distributions over the stellar magnitudes of the internal errors of a single measurement of the stellar magnitude after reduction into the Johnson BVR system 


\section{Conclusion}

The processing of observations showed the possibility of carrying out differential observations on the telescope Zeiss-1000 with an accuracy of one observation, not worse than 0.04", and near 0.02" after improving telescope management.

Photometric estimate of the accuracy of the observations was obtained. The internal errors of one measurement of the stellar magnitude in the instrumental system bvr have the values $\sigma_{\mathrm{bvr}}=(0.03-0.05)^{\mathrm{m}}$. After the reduction of instrumental stellar magnitudes to the Johnson BVR system, the errors of one measurement are $\sigma_{\mathrm{BVR}}=$ $(0.05-0.08)^{\mathrm{m}}$.

Astrometric and photometric studies of CCD observation of clusters on Maidanak observatory continue.

\section{References}

Andruk V.M., Pakuliak L.K., Golovnia V.V. et al.: 2017, Scince and Innovation, 13(1), 17.
Andruk V.M., Vidmachenko A.P., Ivashchenko Yu.M.: 2005, Kinem. Phys. Cel. Bodies., Suppl. 5, 544.

Apogee Alta CCD Camera, [online] Available at: (https:/optcorp.com/products/apogee-alta-f9000-d07monochrome-ccd-camera)

Gaia Collaboration: 2018, $A \& A, \mathbf{6 1 6}, \mathrm{A} 14$.

Protsyuk Yu.I., Martynov M.V., Mazhaev A.E. et al.: 2014, Kinem. Phys. Cel. Bodies., 30, N6, 296.

Protsyuk Yu.I., Andruk V.M., Kazantseva L.V.: 2014, Odessa Astron. Publ., 27, 59.

Raab H., Astrometrica, [online] Available at: (http://www.astrometrica.at/)

Relke E., Protsyuk Yu.I., Andruk V.M.: 2015, Odessa Astron. Publ., 28, 211.

Vavilova I.B., Pakulyak L.K., Shlyapnikov A.A. et al.: 2012, Kinem. Phys. Cel. Bodies, 28, N4, 85.

Vavilova I.B., Yatskiv Ya.S., Pakuliak L.K. et al: 2017, IAUS, 325, 36.

Zacharias N., Finch C.T., Girard T.M. et al.: 2013, Astron. J. 145, 44 . 